\title{
PERBEDAAN PEMASANGAN KATETER DENGAN MENGGUNAKAN JELLY YANG DIMASUKKAN URETRA DAN JELLY YANG DIOLESKAN DI KATETER TERHADAP TINGKAT NYERI PASIEN
}

\author{
${ }^{1}$ Oktovina Mobalen, ${ }^{2}$ Tansar, ${ }^{3}$ Yehud Maryen \\ ${ }^{1,2,3}$ Politeknik Kesehatan Kemenkes Sorong \\ email:omobalen@gmail.com
}

\author{
Artikel History \\ Dikirim, Desember $13^{\text {th }}, 2019$ \\ Ditinjau, Desember $16^{\text {th }}, 2019$ \\ Diterima, Desember $19^{\text {th }}, 2019$
}

\begin{abstract}
Elimination is one of the fulfillment of human physiological needs. Disruption of elimination indicates the occurrence of interference on the part of the urinary system, causing an inconvenience in daily life and can interfere the activity. Urinary catheter is an invasive procedure that putting a tube into the bladder which aims to help out the urine. This action can save lives, especially when the urinary tract is blocked or the patient is unable to urinate. This study was conducted to determine the comparison of pain response in male urinary catheterization procedures with applicating the jelly on the catheter technique and spraying directly into the urethra. This study is a kind of experiment using quasiexperimental design. Total sample of 30 respondents conducted by kuota sampling. The analysis of this study used the mann-whitney test, the results of the study showed that there was a significant difference between the jelly that was inserted with the dilethra and the jelly applied to the catheter to the level of the patient's pain.
\end{abstract}

Keywords: Catheterization, Jelly, Pain Response

\section{ABSTRAK}

Eliminasi merupakan salah satu pemenuhan kebutuhan fisologis manusia. Terganggunya eliminasi menandakan terjadinya gangguan pada bagian sistem perkemihan sehingga menimbulkan ketidaknyamanan dalam kehidupan sehari - hari dan dapat mengganggu aktivitas.Pemasangan kateter urin merupakan suatu tindakan invasif dengan memasukkan selang ke dalam kandung kemih yang mana bertujuan untuk membantu dalam mengeluarkan urin.Tindakan ini dapat menyelamatkan kehidupan, khususnya bila saluran kemih tersumbat atau pasien tidak dapat melakukan pengeluaran urin. Penelitian ini dilakukan untuk mengetahui perbandingan respon nyeri pada prosedur kateterisasi urin pria dengan teknik pengolesan jelly pada kateter dan penyemprotan jelly langsung ke dalam urethra. Jenis penelitian adalah eksperimen dengan desain quasi eksperimen. Jumlah sampel 30 responden yang dilakukan dengan kuota sampling. Analisa penelitian ini menggunakan uji mann-whitney, hasil penelitian menunjukkan ada perbedaan yang bermakna antara jelly yang dimasukan diuretra dan jelly yang dioleskan di kateter terhadap tingkat nyeri pasien.

Kata Kunci: Kateterisasi, Jelly, Respon Nyeri 
Nursing Arts, Vol.XIII, No 02, Desember 2019

\section{PENDAHULUAN}

\begin{tabular}{lrrrl}
\multicolumn{1}{c}{ Eliminasi } & merupakan & salah $\quad$ satu & mencapai 13 juta dengan 85 persen diantaranya \\
pemenuhan & kebutuhan & fisologis & laki-laki. Jumlah ini sebenarnya masih sangat \\
manusia.Terganggunya eliminasi & menandakan & sedikit dari kondisi sebenarnya, sebab masih
\end{tabular}
terjadinya gangguan pada bagian sistem banyak kasus yang tidak dilaporkan ${ }^{3}$.

perkemihan baik karena cidera ataupun penyakit

Lebih dari 30 juta kateterisasi urin seperti retensi urin, batu ginjal, inkonentsia urin, dilakukan setiap tahun di Amerika Serikat, yaitu atau BPH (benigna prostat hipertropi) sehingga berkisar $10 \%$ pada pasien akut dan 7,5\% sampai menimbulkan ketidaknyamanan dalam kehidupan dengan $10 \%$ pada pasien yang memerlukan sehari - hari dan dapat mengganggu aktivitas.Pentingnya eliminasi atau pengeluaran urin dengan lancar, salah satu tindakan keperawatan kolaborasi yang sering dilakukan perawat di rumah sakit yang berkaitan dengan pemenuhan kebutuhan eliminasi adalah pemasangan kateter ${ }^{1}$.

Dalam prosedur tetap tindakan
pemasangan kateter dapat dilakukan oleh petugas fasilitas perawatan jangka panjang, angka ini diperkirakan akan meningkat hingga mencapai $25 \%$. Banyak alasan yang membuat peningkatan tindakan kateterisasi urin, mencakup kompleksitas perawatan dan tingkat keparahan penyakit ${ }^{4}$. Di Indonesia sekitar 5,8 persen penduduk Indonesia menderita inkontinensia urin. Jika kesehatan yaitu Dokter dan Perawat. Sebagai seorang Petugas Kesehatan khususnya Perawat diharapkan dalam melakukan suatu tindakan dapat memahami dan mengerti betul tentang anatomi, teknik komplikasi / risiko dari suatu tindakan termasuk $^{2}$. mengganggu dan atau depresi pada sehingga

Kateterisasi urin merupakan salah satu menimbulkan rasa rendah diri membuat malu, tindakan untuk membantu eliminasi urin maupun penderitanya ${ }^{5}$.

ketidakmampuan melakukan urinasi. Banyak klien Pada survei pendahuluan yang dilakukan oleh merasakan cemas, takut akan rasa nyeri dan penulis pada tanggal 05 mey 2017 di dapatkan ketidaknyamanan dalam menghadapi kateterisasi pasien yang mengunakan kateter di RSUD Sele Be urin. Mereka terlihat emosional menghadapi Solu Kota Sorong sebesar 90 orang per 3 bulan, tindakan-tindakan pengobatan maupun perawatan, dari Bulan Januari, Ferbuari dan Maret 2017.

terlebih yang berhubungan dengan daerah Untuk mengurangi nyeri saat pemasangan urogenital yaitu saat kateter menembus masuk ke kateter urin adalah dengan menggunakan jelly dalam tubuh ${ }^{2}$. pelumas. Ada dua alternatif dalam penggunaan Menurut data dari WHO, 200 juta jelly pelumas, yang pertama dengan mengolesi penduduk dunia mengalami inkontinensia urin. Di jelly pada selang kateter di sepanjang selang yang Amerika Serikat, jumlah penderita inkontinensia akan dimasukkan ke dalam urethra setelah diukur, 
dan yang kedua dengan memasukkan jelly pada uretra di Instalasi Gawat Darurat RSU Prif. R.D urethra dengan menggunakan spuit ${ }^{5}$.

kandou Manado sebagai besar mengalami nyeri

Dari kedua alternatif tersebut, tampaknya berat $86,7 \%$ dan sisa dalam kategori berat $(13,3)$. alternatif pertama masih menjadi primadona dalam Sedangkan tingkat nyeri pasien yang di pasangan prosedur pemasangan kateter di rumah sakit. kateter dengan jelly yang di oleskan pada kateter Berbeda dengan Ferdinan .dkk $(2003)^{6}$, bahwa di Instalasi Gawat Darurat RSU Prif. R.D kandou cara memasukkan jelly langsung ke dalam uretra Manadosebagaia besar mengalami nyeri sedang dapat memengaruhi kecepatan dalam pemasangan $66,7 \%$ dan sisanya dalam kategori sedang. selang kateter sehingga dapat mengurangi iritasi Garbutt, David, Victor, \& Michael pada dinding uretra akibat dari pergesekan dengan $(2012)^{9}$, kateterisasi urin termasuk dalam empat selang kateter dibandingkan dengan cara besar sebagai prosedur yang paling menimbulkan pelumasan jelly pada kateter. nyeri selama masa perawatan di rumah sakit.

Berdasarkan hasil studi mengenai dampak Sekitar 32\% dari kateterisasi urin menyebabkan kateterisasi urin pada laki-laki terhadap respon trauma iatrogenik, dari jumlah tersebut 52\% nyeri yang dialami, diketahui bahwa 86,7\% dari 15 mempengaruhi uretra bulbar dan atau prostatik pasien yang menjalani kateterisasi urin dengan (Djakovic, Plas, Martínez, \& Lynch, 2012). jelly biasa yang dimasukkan ke uretra mengalami Komplikasi dari kateterisasi urin menyebabkan nyeri dengan kategori sedang dan 13,3\% ketidak- mampuan melakukan perawatan diri dan mengalami nyeri kategori berat, sementara dari 15 mempengaruhi kualitas hidup individu.

pasien yang menjalani kateterisasi urin dengan

Melihat fenomena tersebut, peneliti jelly yang dioleskan ke selang kateter $66,7 \%$ tertarik untuk mengetahui apakah ada diantaranya mengalami nyeri kategori berat dan perbandingan respon nyeri pada prosedur 33,3\% mengalami nyeri kategori sangat berat kateterisasi urin pria dengan teknik pengolesan (Riadiono, Handoyo, \& Dina, 2008). Pada studi jelly pada kateter dan penyemprotan jelly langsung lain dari 25 pasien laki-laki yang menjalani ke dalam uretra ${ }^{1}$.

tindakan kateterisasi urin 52\% mengalami nyeri METODE

kategori sedang dan $12 \%$ mengalami nyeri kategori berat ${ }^{7}$.

Desain penelitian ini adalah quasi

Berbeda dengan penelitian (Frenky Tahun eksperiment, jumlah sampel sebanyak 30 $2012)^{8}$ dengan judul yang sama meneliti di kota Manado di RSU Prof. Dr. R.D kandou Manado mengatakan tingkat nyeri pasien yang di Be Solu Kota Sorong Pada bulan agustus Tahun pasangkan kateter dengan jelly yang di masukan 2017. 


\section{HASIL}

\section{Univariat}

Tabel 1. Distriusi Responden Berdasarkan Waktu Yang Di Rasakan Nyeri

\begin{tabular}{llcc}
\hline No & Waktu rasa nyeri & Frekwensi & Presentasi \\
\hline 1 & Saat di masukan & 28 & $93.33 \%$ \\
\hline 2 & Setelah di masukan & 2 & $6.67 \%$ \\
\hline
\end{tabular}

Berdasarkan tabel 1 maka dapat yang dirasakan nyeri saat di masukan yaitu diketahui bahwa responden penelitian sebanyak 28 orang atau $93.33 \%$. didominasi oleh responden dengan waktu

Tabel 2. Distriusi Responden Berdasarkan Waktu Yang Di Rasakan Nyeri

\begin{tabular}{llcc}
\hline No & Waktu rasa nyeri & Frekwensi & Presentasi \\
\hline 1 & Saat di masukan & 28 & $93.33 \%$ \\
\hline 2 & Setelah di masukan & 2 & $6.67 \%$
\end{tabular}

Berdasarkan tabel 2, maka dapat diketahui bahwa responden penelitian didominasi oleh responden dengan waktu yang dirasakan nyeri saat di masukan yaitu sebanyak 28 orang atau $93.33 \%$.

Tabel 3.Distribusi Responden Berdasarkan Durasi Nyeri

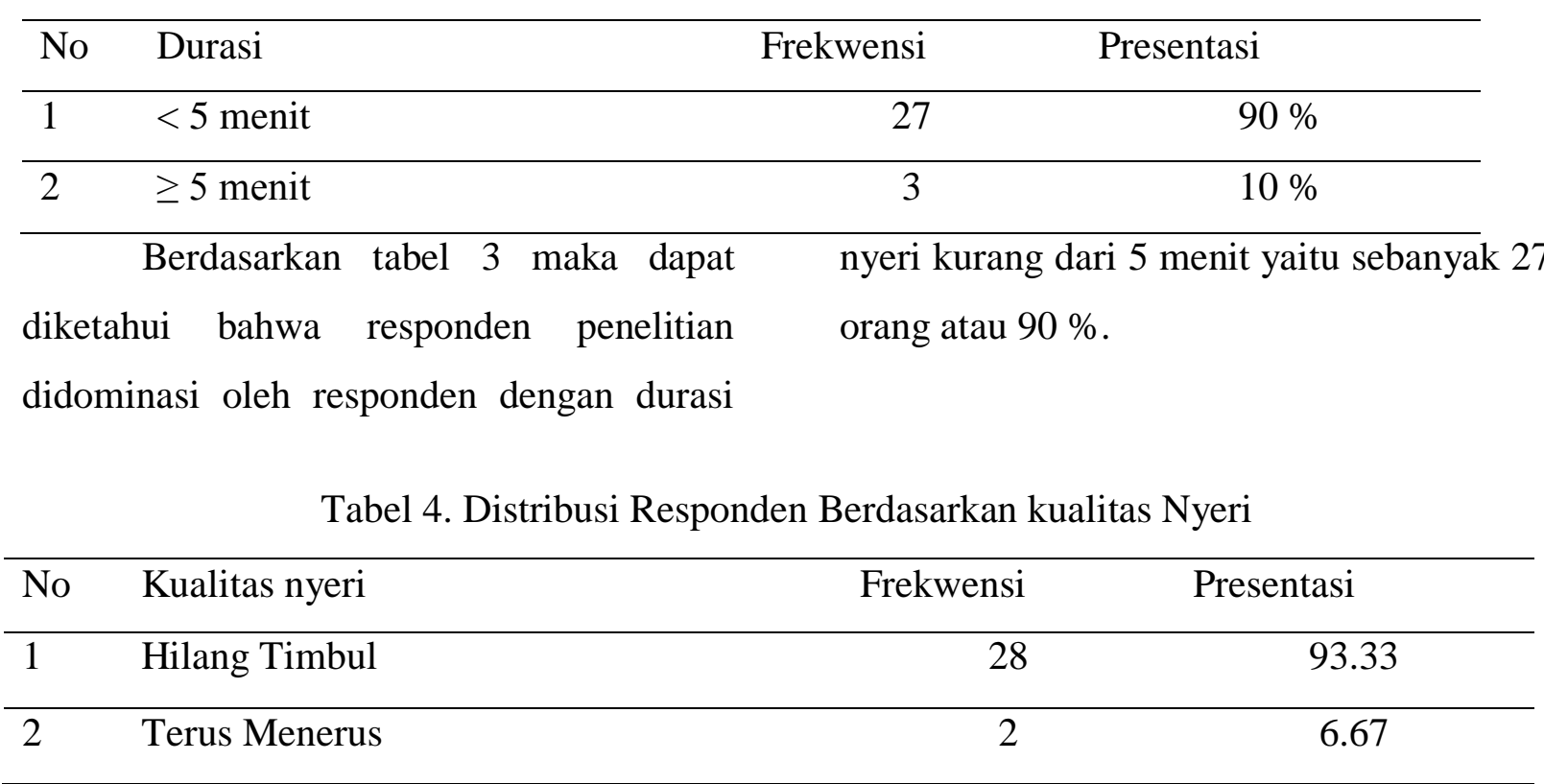


Berdasarkan tabel 4 maka dapat diketahui bahwa responden penelitian didominasi oleh responden dengan kualitas nyeri hilang timbul yaitu sebanyak 28 orang atau $93.33 \%$.

\section{Bivariat}

Tabel 5. Hasil Analsis Bivariat

\begin{tabular}{lllll}
\hline NO & \multicolumn{1}{c}{ Teknik pemasngan } & $\mathrm{n}$ & Mean Rank & Sun of Ranks \\
& & & & \\
\hline 1 & Jelly yang dimasukan diuretra & 15 & 12.00 & 180.00 \\
\hline 2 & Jelly yangdioleskan & 15 & 19.00 & 285.00 \\
\hline & Total & 30 & & \\
\hline & Asymp. Sig (2-tailed) & & .027 & \\
\hline
\end{tabular}

Untuk mengetahui perbedaan pemasangan kateter dengan mengunakan jelly yang dimasukkan diuretra dan jelly yang di oleskan di kateter terhadap respon nyeri dilakukan uji statistik mann-whitney dengan bantuan komputer program SPSS for windows versi 16.

\section{PEMBAHASAN}

Hasil penelitian menunjukan bahwa ada perbedaan antara pemasangan kateter mengunakan jelly yang di masukan diuretra dan jelly yang di oleskan di kateter terhadap tingkat nyeri pasien di RSUD Sele Be Solu Kota Sorong. Penelitian ini sama dengan hasil penelitian Franky R, (2014) $)^{10}$ bahwa ada perbedaan antara pemasangan kateter kateter mengunakan jelly yang di masukan diuretra dan jelly yang di oleskan di kateter terhadap tingkat nyeri pasien, dan berbeda dengan hasil penelitian oleh Riadiono bahwa tidak ada

Nyeri merupakan pengalaman sensorik dan emosional yang tidak menyenangkan akibat
Berdasarkan hasil uji statistik dengan tingkat kepercayaan 95\%, df:3, a = 0,05 didapatkan hasil $r=0,027$. Ini berarti, $r<a$ $(0,27<0,05)$. Jika $r<$ a, maka Ha diterima dan Ho ditolak. Kesimpulan yang didapat yaitu ada perbedaan yang bermakna antara jelly yang dimasukan diuretra dan jelly yang dioleskan di kateter terhadap tingkat nyeri pasien.

perbedaan antara kateter mengunakan jelly yang di masukan diuretra dan jelly yang di oleskan di kateter terhadap tingkat nyeri pasien.

Penelitian ini berbeda disebabkan riadiono mengunakan jelly dengan jumlah $2 \mathrm{cc}$ Dari jelly yang di gunaka peneliti mengunakan 3- 3,5 cc jelly yang di ukur di dispo ini untuk mencegah terjadinya pada saat diseprotkan pada uretra akan mengalami kerfluk keluar sedangkan peneliti Riadiono mengunakan jelly lebih sedikit yaitu $2 \mathrm{cc}$, jika jelly yang di masukan sedikit akan merasang nyeri ${ }^{11}$.

kerusakan jaringan, baik aktual maupun potensial, atau yang digambarkan dalam bentuk 
kerusakan tersebut. Sedangkan The International Association for the Study of Pain (IASP) mendefinisikan nyeri sebagai pengalaman sensorik dan emosional yang tidak menyenangkan terkait dengan kerusakan jaringan baik aktual maupun potensial atau yang digambarkan dalam kerusakan tersebut. Kedua pengertian ini memperjelas bahwa nyeri adalah bagian dari proses patologis ${ }^{2}$.

Tindakan kateterisasai merupakan tindakan invasif dan dapat menimbulkan rasa nyeri sehingga jika dikerjakan secara keliru akan menimbulkan kerusakan urethra. Nyeri merupakan keluhan utama yang sering dialami oleh pasien dengan kateterisasi urin karena tindakan memasukkan selang kateter dalam kandung kemih mempunyai resiko terjadinya infeksi atau trauma pada urethra ${ }^{12}$.

Risiko trauma berupa iritasi pada dinding urethra lebih sering terjadi pada pria karena keadaan urethranya yang lebih panjang dan berliku-liku dari pada wanita serta membran mukosa yang melapisi dinding uretra sangat mudah rusak oleh pergesekan akibat dimasukkannya selang kateter Pada pasien pria, teradapat dua alternatif penggunaan jelly pelumas. Yang pertama dengan mengolesi jelly pada selang kateter di sepanjang selang yang akan dimasukkan ke dalam urethra setelah diukur, dan yang kedua dengan memasukkan jelly pada meatus urethra dengan menggunakan spuit $^{12}$.

Terkadang saat selang kateter dimasukkan, banyak jeli yang tertinggal atau bahkan keluar sebelum selang kateter tersebut tuntas dimasukkan. Upaya memasukkan jeli 33,5 cc terlebih dahulu ke dalam uretra diasumsikan bahwa seluruh dinding uretra pada pria sepanjang $12-17 \mathrm{~cm}$ telah telumuri jeli sebelum kateter dimasukkan. Sehingga meminimalkan terjadinya pergesekan antara dinding uretra dengan kateter yang akan meminimalkan efek nyeri. Selain itu jumlah jeli yang masuk dalam uretra juga terukur untuk semua responden. Sedangkan bila menggunakan jeli yang dilumurkan pada kateter yang akan dipasang, kemungkinan jumlah jeli yang digunakan dan panjang kateter yang dilumuri jeli antar sesama perawat yang akan memasang kateter relative tidak sama, hal ini akan mengakibatkan respon nyeri klien yang berbeda-beda.

Ini dapat dilihat dari banyak factor yang mengakibatkan nyeri salah satunya adalah usia dapat dilihat saat peneliti meneliti usia 56 sampai 65 sedikit yang mengalami nyeri hal ini sesuai dengan teori yang dikemukakan Zatzick \& Dimsdale $(2010)^{13}$ bahwa dewasa tua akan memiliki intensitas nyeri lebih rendah dibandingkan dengan usia sebelumnya. Hal ini terjadi karena dewasa memiliki pengalaman lebih banyak terhadap berbagai rasa nyeri yang pernah dialaminya, selain itu dewasa tua sudah lebih baik dalam mengungkapkan perasaan nyeri yang dialaminya secara verbal.

Cara memasukkan jeli langsung ke dalam uretra dapat mempengaruhi kecepatan pemasangan kateter sehingga mengurangi tingkat iritasi pada dinding uretra akibat pergesekan dengan kateter bila dibandingkan dengan cara pelumasan dengan melumuri jeli pada ujung kateter (Ferdinan, Pahria, 2003) ${ }^{14}$. Iritasi jaringan atau nekrosis dapat juga diakibatkan oleh pemakaian kateter yang 
ukurannya tidak sesuai besarnya orifisium uretra, kurangnya pemakaian jeli, penekanan yang berlebihan, misalnya memfiksasi terlalu

\section{SIMPULAN}

Bedasarkan hasil penelitian dan pembahasan tentang perbedaan pemasangan kateter mengunakan jelly yang yang di masukan diuretra dan jelly yang dioleskan dikateter terhadap tingkat nyeri, maka penulis dapat

\section{UCAPAN TERIMA KASIH}

Terimakasih peneliti ucapkan kepada direktur RSUD Sele Be Solu Kota Sorong yang

\section{DAFTAR RUJUKAN}

1. Dorhorty, (2006). Hubungan Pemasangan Kateter Dengan Kejadian Infeksi Saluran Kemih Dan Terjadinya Bakteri Di urin. Skripsi Keperawatan Medikal Bedah, 7, 3236.

2. Esho, (2014). teknik pemasangan kateter mengunakan jelly yang dimasuk di uretra dan yang di oleskan di kateter terhadap respon nyeri pasien.

3. Herman (2012) pemasangan kateter terhadap respon nyeri pasien dan metode manajemen nyeri. Keperawatan Gawat Darurat Dan Menajen Nyeri, 2 london, 12.

4. Hampton, 2005 ubungan pemasangan kateter dengan kejadian infeksi saluran kemih dan terjadiya bakteri di urin. Skripsi Keperawatan Medikal Bedah, 7, 32-36.

5. Hidayat. (2006). Management of short term indwelling urethral catheters to prevent urinary tract infections. Diakses dari www.joannabriggs.edu.au pada tanggal 10 mei 2014 erat dan penggunaan kateter intermiten yang terlalu sering dapat merusak jaringan kulit.

simpulkan ada perbedaan antara pemsangan kateter dengan mengunakan jelly yang yang di masukan diuretra dan jelly yang dioleskan dikateter terhadap tingkat nyeri di RSUD Sele Be Solu Kota Sorong.

telah membantu dalam melakukan penelitian ini.

6. Indrawaty. (2015). manajemen nyeri dan intesitas nyeri. Keperawatan Manajemen Nyeri, 7, 54.

7. Jayanty, N. (2016). keperawatan kateter dan keperawatan saluran eliminasi. Buku Saku Keperawtan, 33, 12-43.

8. Japardi. (2010). Management of short term indwelling urethral catheters to prevent urinary tract infections. Diakses dari www.joannabriggs.edu.au pada tanggal 10 mei 2014. Respon, P., Pada, N., Urin, K., Dengan, P., Pengolesan, T., Pada, J., ... Instalasi, D. I. (2015). Program Studi Keperawatan.

8. Riadiono, B., S, D. I. D., Keperawatan, J., Universitas, F., \& Soedirman, J. (2008). Jurnal Keperawatan Soedirman (The Soedirman Journal of Nursing), Volume 3 No.2 Juli 2008, 3(2), 95-100.

9. Dika (2013) pemasangan kateter terhadap respon nyeri pasien dan metode manajemen nyeri. Keperawatan Gawat Darurat Dan Menajen Nyeri, 2 london, 12. 
10. Risnawati (2014) buku saku keperawatan sistem eliminasi dan EKG dan cara kerjanya. Buku Saku Keperawatan Medikal Bedah Sistem Eliminasi, 5, 5.

11. Larasanti (2013) buku saku keperawatan sistem eliminasi dan EKG dan cara kerjanya. Buku Saku Keperawatan Medikal Bedah Sistem Eliminasi,

12. Roberto, F. (2015). sistem eliminasi urin. Keperawatan Gawat Darurat Dan Sistem Eliminasi, 4, 22.

13. Rosmiati, (2014). Teknik pemasangan kateter mengunakan jelly yang dimasuk di uretra dan yang di oleskan di kateter terhadap respon nyeri pasien. Skripsi Keperawatan Medikal Bedah,

14. Franky, (2014). Hubungan Antara Lama Waktu Terpasang Kateter dengan Kecemasan pada Klien yang Terpasang Kateter Urethra di Bangsal Rawat Inap Dewasa Kelas III RS PKU Muhammadiyah Yogyakarta. Karya Tulis Ilmiah. Tidak Dipublikasikan. UMY: Yogyakarta
15. Garbertt, David, Victor \& michael, (2012) teknik pemasangan kateter mengunakan jelly yang dimasuk di uretra dan yang di oleskan di kateter terhadap respon nyeri pasien. Skripsi Keperawatan Medikal Bedah,

16. Ferkovan, H. (2013). pemasangan kateter terhadap respon nyeri pasien dan metode manajemen nyeri. Keperawatan Gawat Darurat Dan Menajen Nyeri, 2 london, 12 ..

17. Rudianto. (2015). manajamen nyeri. Ilmu Keperawatan Manajemen Nyeri, 6, 32.

18. Saputra, B. (2010). keperawatan manajemen nyeri. Ilmu Keperawatan, 1, 21.

19. Sari, M. (2015). buku saku eliminasi dan pola terjadinya batu ginjal. Keperawatan Eliminasi, 5, 43.

20. Sataria, S. (2014). jurnal keperawatan skripsi lengkap keperawatan kateter terhadap resiko infeksi. Skripsi Keperawatan, 3, 21. 